\title{
Właściwości normalizowanej stali zlewnej mostu kolejowego po 75 latach eksploatacji
}

\author{
Properties of normalized cast steel \\ of the railway bridge after 75 years of exploitation
}

\section{Streszczenie}

Przedstawiono badania materiałowo - wytrzymałościowe stali mostu kolejowego wybudowanego w roku 1938. Omówiono stan techniczny konstrukcji obiektu przed remontem i zakres prac modernizacyjnych. Przeprowadzono spektrometryczną analizę chemiczną stali oraz badania jej twardości i statycznego rozciągania, a spawalność określono na podstawie obliczonych wskaźników spawalności. Wyniki z badań wykazały, że jest to prawdopodobnie stal zlewna normalizowana gatunku St37 12, której produkcję w Niemczech rozpoczęto w końcu XIX wieku.

Słowa kluczowe: mosty stalowe, stal normalizowana, spawalność

\section{Abstract}

The paper presents the study of strength and material properties of steel of the railway bridge built in 1938. The technical condition of the bridge before repair as well as renovation works are presented. Spectrometric chemical analyses of structural steel as well as hardness and static tensile tests were carried out. Measured parameters of cast steels are presented. These are priority investigations of normalized cast steel.

Keywords: steel bridges, cast steel, weldability

\section{Wstęp}

Problematyka trwałości stalowych konstrukcji mostowych jest dziś bardzo aktualną. W Polsce 43,4\% kolejowych obiektów mostowych ma powyżej 100 lat, a kolejne $33 \%$ od 50 do 100 lat i właśnie teraz część z nich wymaga modernizacji, remontu lub rozbiórki $[1 \div 4]$. Dlatego celowe jest prowadzenie diagnostycznych badań mostów użytkowanych przez dłuższy czas. Badania konstrukcji in situ stanowią metodę poznawania ich właściwości we wszystkich uwarunkowaniach: geometrycznych, technologicznych oraz eksploatacyjnych.

Przydatnym są tutaj badania próbek materiałowych pozyskanych z eksploatowanych konstrukcji, które pozwalają oszacować starzenie strukturalne stali i określić jej aktualne

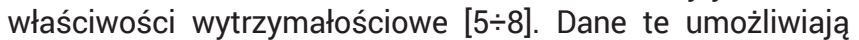
obniżenie poziomu niepewności, co do wartości parametrów, które są wykorzystane do określenia bezpieczeństwa obiektu mostowego. Pewnym przyczynkiem, pozwalającym na uzyskanie dodatkowych informacji na powyższy temat, może być przedstawiona w niniejszym referacie analiza właściwości stali z mostu kolejowego eksploatowanego przez 77 lata.

\section{Charakterystyka mostu}

Przedmiotowy most przez rzekę Wartę usytuowany jest na jednotorowej linii kolejowej nr 367. Schemat konstrukcyjny

obiektu przedstawiono na rysunku 1. Most ma osiem przęseł o rozpiętościach: od 26,00 do 95,80 m. Długość całkowita wynosi 315,57 m, a jego światło 302,67 m. Most został zbudowany przez Niemców w 1938 r, ze stali zlewnej niskowęglowej gatunku St 37. Według DIN 1612 o wartościach $R_{m}=370 \div 450$ $\mathrm{MPa}, R_{e}=240-280$ i $k=140(160) \mathrm{MPa}[9,10]$. Siedem przęseł to blachownicowe konstrukcje nitowane $\mathrm{z}$ jazdą dołem oraz jedno przęsło kratownicowe (rys. 2 i 3 ).
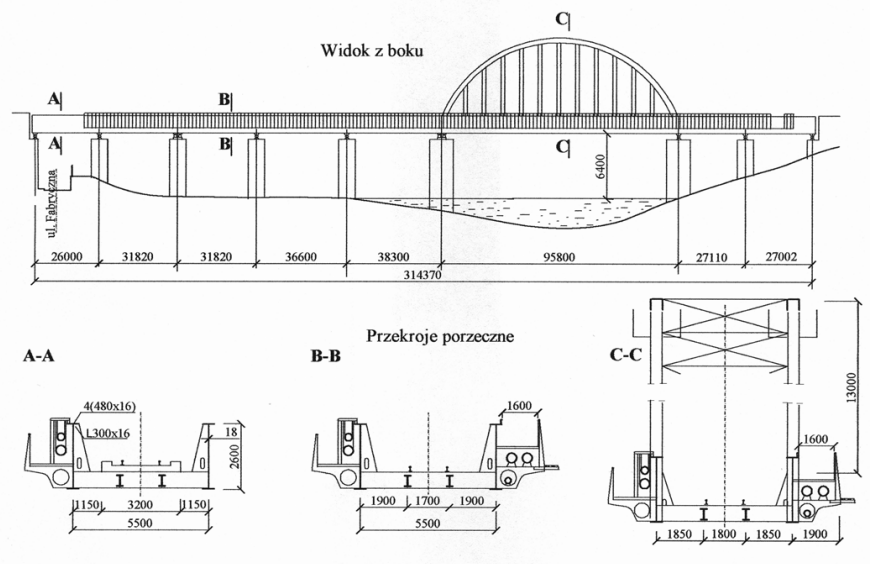

Rys. 1. Konstrukcja mostu (widok boczny i przekroje poprzeczne) Fig. 1. Bridge structure (side view and cross - sections)

Dr hab. inż. Bernard Wichtowski, prof. ZUT, mgr inż. Zdzisław Woźniak - Zachodniopomorski Uniwersytet Technologiczny w Szczecinie. 


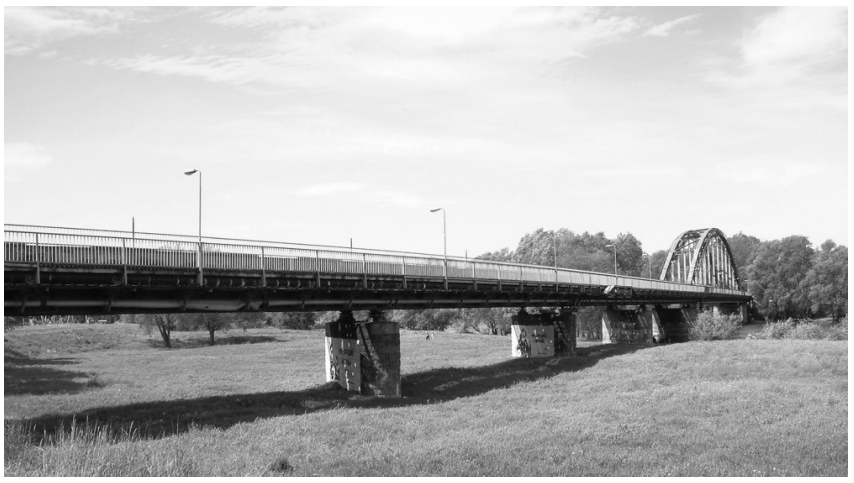

Rys. 2. Widok ogólny 5 przęseł mostowych

Fig. 2. General view of 5 bridge plate girders

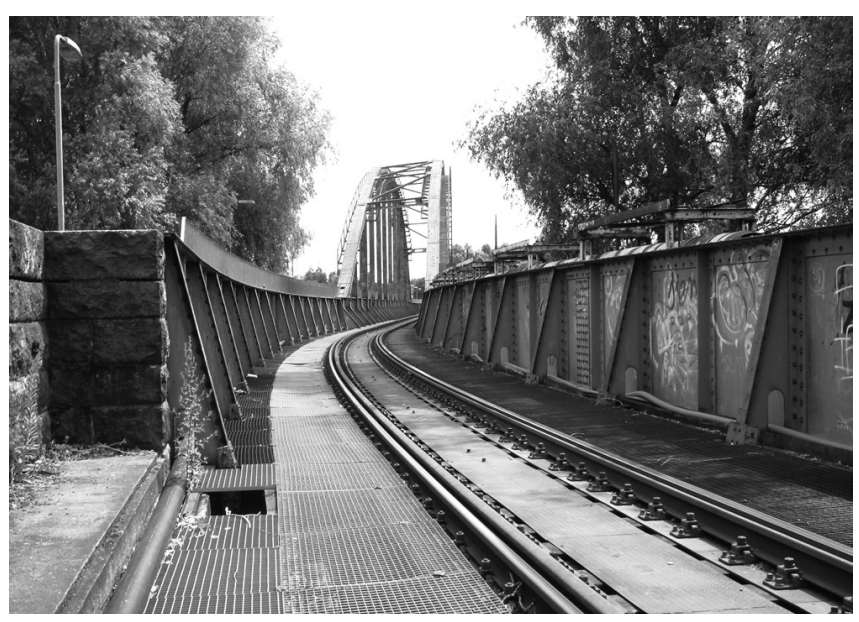

Rys. 3. Jezdnia mostowa

Fig. 3. Bridge deck

W styczniu 1945 r. konstrukcja została częściowo zniszczona. Uszkodzenie polegało na wysadzeniu trzech filarów, aż do fundamentów i zatopieniu całej stalowej konstrukcji przęsła nurtowego. Odbudowę mostu wykonano w roku 1965. Przęsło nurtowe zaprojektowano, jako wolnopodparte belki blachownicowe wzmocnione łukiem (konstrukcja Langera). Łuk wykonstruowano o przekroju skrzynkowym, a jego węzły leżą na paraboli drugiego stopnia o strzałce $14 \mathrm{~m}$. Przęsło o konstrukcji nitowanej zaprojektowano na obciążenie ruchome NL (20 t na oś). Jako materiał na elementy kratowe i blachownicowe dźwigary nośne przyjęto stal gatunku St18G2, na elementy jezdni oraz dwuteowe wieszaki spawane i elementy tężników - stal St3M, a na pozostałe elementy stal St3S.

W trakcie odbudowy mostu zaprojektowano dwustronne chodniki publiczne o szerokości 1,5 m, przykryte prefabrykowanymi płytami żelbetowymi o grubości $60 \mathrm{~mm}$, dla umożliwienia mieszkańcom miasta przejścia na drugą stronę Warty. Przynitowane do dźwigarów mostowych wsporniki chodników, w rozstawie osiowym, co 4,0 m są odpowiednio wyprofilowane, co umożliwia na nich również założenie rurociągów i kabli energetycznych (rys. 4).

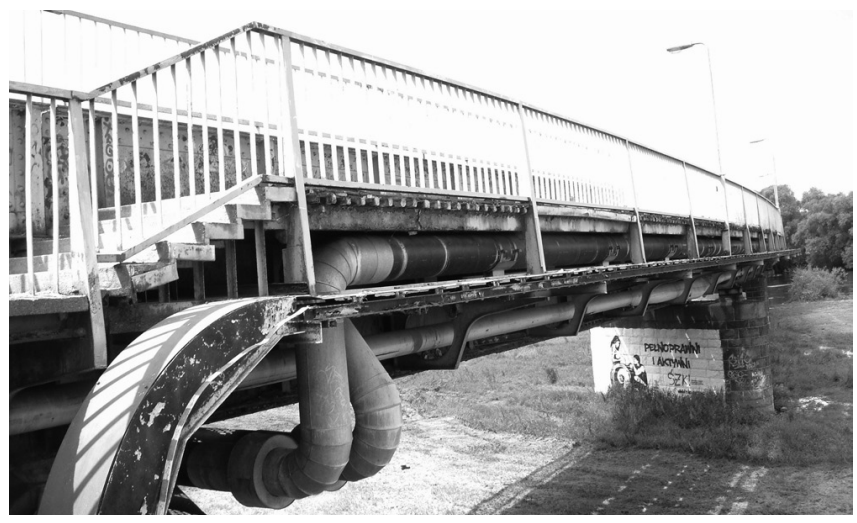

Rys. 4. Chodnik na moście stan obecny

Fig. 4. Sidewalk on the bridge - the current state

\section{Skład chemiczny stali}

W ramach projektu nowej konstrukcji chodnika dla pieszych, na kładce mostowej od strony wody wysokiej zaistniała konieczność wykonania obliczeń statyczno-wytrzymałościowych nośnych elementów mostowych. Fakt ten oraz ewentualność prowadzenia spawania podczas prac restytucyjnych, wymagał oceny aktualnych właściwości stali celem oceny jej wytrzymałości obliczeniowej oraz spawalności. Próbki do badań wycięto: - ze środnika strefy $(\mathrm{t}=18 \mathrm{~mm})$ końcowej (poza łożyskiem) dźwigara skrajnego mostu o długości 26,0 m.

Spektrometryczna analiza chemiczna stali z pobranych próbek wykazała skład chemiczny podany w tablicy I. W tablicy tej analizę składu chemicznego przedstawiono dla wybranych 9 zasadniczych pierwiastków stopowych z analizy 18 pierwiastków otrzymanych w badaniach. Jednocześnie w celach porównawczych podano skład chemiczny stali:

- zlewnej stosowanej przez Niemcy do budowy mostów w latach $1856 \div 1950[7,8]$,

- St 373 wg DIN 17100 - 80, która jako jedyna była specjalnie uspokojona.

Z analizy składu chemicznego poszczególnych gatunków stali wynika, że konstrukcja mostu została wykonana ze stali zlewnej niskowęglowej, prawdopodobnie ze stali gatunku St $37 \mathrm{wg}$ DIN 1612 [9]. Była to według tej normy jedyna stal wyżarzona normalizująco o $\mathrm{R}_{m}=370-450 \mathrm{MPa}$ i min $A_{5}=18 \div 25 \%$. Cechą charakterystyczną stali zlewnych tego gatunku jest mała zawartość węgla. Jest to czynnik niekorzystny, ponieważ szybkość starzenia zwiększa się, gdy zawartość węgla jest mniejsza niż 0,10\%. Mała jest również zawartość siarki, fosforu i krzemu. Według DIN 1050 z 1937 r. dla stali tej wartości naprężenia dopuszczalnego wynoszą: I - 140 i II - $160 \mathrm{MPa}$.

Rodzaj obciążenia I - składa się z jednoczesnego, niekorzystnego działania obciążenia stałego oraz obciążeń zmiennych wraz ze śniegiem (ale bez wiatru); II rodzaju - składa się z obciążeń I rodzaju oraz działania wiatru i wpływu zmian temperatury.

Tablica I. Skład chemiczny stali mostu i stali porównawczych

Table I. Chemical composition of bridge steel and compared steel

\begin{tabular}{|c|c|c|c|c|c|c|c|c|c|}
\hline \multirow{2}{*}{ Rodzaj stali } & \multicolumn{9}{|c|}{ Skład chemiczny, \% wag. } \\
\hline & C & $\mathrm{Mn}$ & Si & $\mathrm{P}$ & $\mathrm{S}$ & $\mathrm{Cu}$ & $\mathrm{Cr}$ & $\mathrm{Ni}$ & Al \\
\hline $\begin{array}{c}\text { Dźwigar } \\
\text {-środ. } t=18\end{array}$ & 0,0838 & 0,460 & 0,045 & 0,006 & 0,026 & 0.156 & 0.018 & 0,031 & 0.035 \\
\hline $\begin{array}{c}\text { Stal } \\
\text { zlewna }\end{array}$ & $\begin{array}{c}0,030 \\
\div 0,350\end{array}$ & $\begin{array}{c}0,040 \\
\div 0,750\end{array}$ & $\begin{array}{l}\text { ślady } \\
\div 0,180\end{array}$ & $\begin{array}{c}0,004 \\
\div 0,160\end{array}$ & $\begin{array}{c}0,004 \\
\div 0,115\end{array}$ & $\begin{array}{c}0,110 \\
\div 0,140\end{array}$ & $\begin{array}{c}0,007 \\
\div 0,014\end{array}$ & $\begin{array}{c}0,030 \\
\div 0,040\end{array}$ & $\begin{array}{c}0,010 \\
\div 0,020\end{array}$ \\
\hline St $37-3$ & $\max 0,17$ & - & - & $\begin{array}{l}\max \\
0,040\end{array}$ & $\begin{array}{l}\max \\
0,040\end{array}$ & - & - & - & $\min 0,020$ \\
\hline
\end{tabular}




\section{Właściwości mechaniczne stali}

Właściwości mechaniczne i plastyczne stali blachownicowych dźwigarów nośnych mostu określono na podstawie badań statycznego rozciągania próbek (rys. 5) oraz pomiarów twardości metodą Brinella (tabl. II). Badania statycznego rozciągania próbek okrągłych, pięciokrotnych o średnicy bazowej $10 \mathrm{~mm}$ dotyczyły:

- sześciu próbek ze stali St 37 środnika dźwigara mostowego; w tym trzech próbek z materiału w stanie naturalnym, czyli zestarzonym (S) oraz trzech próbek, które poddano wyżarzaniu normalizującemu (N) w temperaturze $930{ }^{\circ} \mathrm{C}$ przez jedną godzinę i studzeniu na powietrzu.

W wyniku wyżarzania normalizującego uzyskuje się najmniejszą możliwą w tej stali wielkość ziarna. Określone parametry mechaniczne próbek normalizowanych są porównywalne z własnościami stali w fazie dostawy, czyli z cechami stali z okresu budowy mostu. W toku tego zabiegu obróbki cieplnej, wydzielania degradacyjne ulegają rozpuszczeniu w austenicie, a w trakcie chłodzenia na powietrzu uzyskuje się struktury równowagowe. Jak wynika z rysunku 5 i tablicy II, w efekcie starzenia stali zmniejszyły się jej zasadnicze parametry mechaniczne, tj. granica plastyczności i wytrzymałości. Wartość granicy plastyczności, równa min. $R_{e H}\left(R_{e}\right)$ zmniejszyła się o $25 \%$, a wartości średnie dolnej granicy plastyczności $R_{e L}$ oraz granicy wytrzymałości $R_{m}$ odpowiednio o 27 i 10\%; przy raczej stabilnych właściwościach $A_{5}$, Z i HB.

Uzyskane parametry badanej stali mostu są dokładnie zgodne z proponowanymi przez Międzynarodowy Związek Kolejowy UIC, który podaje następujące wartości charakterystyczne [6]:

- wytrzymałość na rozciąganie $R_{m}=320 \div 380 \mathrm{MPa}$,

- granica plastyczności $R_{e}=220 \mathrm{MPa}$.
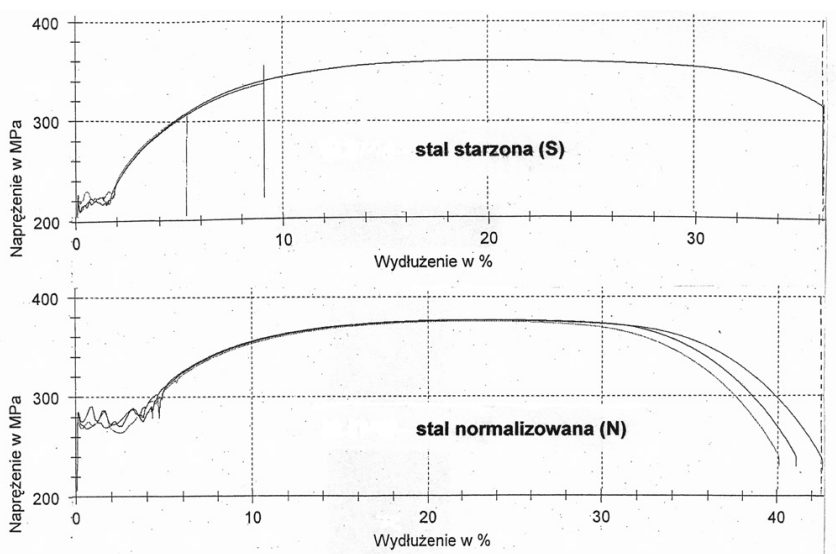

Rys. 5. Wykresy rozciągania próbek ze stali środnika dźwigara głównego

Fig. 5. The schemes of tensile strength of the web of main beam
Wykorzystując próbki przygotowane do badań chemicznych i mechanicznych, przeprowadzono pomiar twardości ich stali metodą Brinella. Badania przeprowadzono twardościomierzem typu B3Cs, używając kulki stalowej średnicy $D=5 \mathrm{~mm}$, przy obciążeniu $P=7350 \mathrm{~N}$ utrzymywanym przez $t=15 \mathrm{~s}$, zgodnie z PN-EN ISO 6506-1: 2002, a uzyskane wyniki przedstawiono w kol. 8 i 9 , tablicy II. Dla stali badanej na rozciąganie statyczne badania te należy traktować, jako uzupełniające. Przyjmując wartość współczynnika $a=R_{e B} / R_{m B}=0,7 \mathrm{wg}$. [7], obliczono wartości granicy plastyczności stali $R_{e B}$ przedstawione w kol. 11. Dla trzech próbek stali badanych na rozciąganie statyczne uzyskane wartości ReB różnią się od wartości $\mathrm{ReH}$ odpowiednio o +14,5; $-9,5$ i $-7,5 \%$.

Ocenę zachowania się stali ze środnika blachownicy mostu w wypadku ewentualnego wystąpienia warunków sprzyjających kruchemu pękaniu spowodowanemu obecnością karbu i odkształceniami o dużej szybkości, powstałymi w wyniku udarowego działania obciążenia, przeprowadzono na podstawie próby udarności. Badania wykonano na próbkach Charpy'ego o wymiarach 10x10x55 mm z karbem V wykonanym wg PN-EN ISO 148-1: 2010. Podobnie jak w badaniach na rozciąganie również udarność określano na dwóch typach próbek:

- starzonych samorzutnie S, czyli próbkach bez dodatkowych zabiegów,

- normalizowanych $\mathrm{N}$.

Wyniki przeprowadzonych badań przedstawiono w tablicy III i graficznie na rysunku 6. Poziomą linią zaznaczono tam wartość udarności na poziomie $34 \mathrm{~J} / \mathrm{cm} 2$, która wymagana jest przez Eurokod 3 (PN-EN1993-1-10) dla próbek o $A=80 \mathrm{~mm}^{2}$ stali stosowanej w nowych konstrukcjach. Badana stal mostu w stanie obecnym, starzonym samorzutnie, wykazała bardzo niską udarność w temperaturze ujemnej. Udarność $\mathrm{w}$ temperaturze $-20 \mathrm{i}-10{ }^{\circ} \mathrm{C}$ wynosi jedynie 12 i $17 \mathrm{~J} / \mathrm{cm}^{2}$, a w $0{ }^{\circ} \mathrm{C}$ tylko $20 \mathrm{~J} / \mathrm{cm}^{2}$. Określona temperatura przejścia w stan kruchy tej stali wynosi $+9{ }^{\circ} \mathrm{C}$ (rys. 6). Zadziwiająco wysoką wartość udarności uzyskano z badań próbek normalizowanych. Udarność stali w fazie dostawy, w okresie budowy mostu, w temperaturze $-20 \mathrm{i}-10{ }^{\circ} \mathrm{C}$ ma wartości $K C V=231$ i $307 \mathrm{~J} / \mathrm{cm}^{2}$, co oznacza, że jest ona 19 i 18 razy większa od udarności próbek starzonych samorzutnie.

„Kosmiczne" wartości udarności próbek normalizowanych świadczą o wyjątkowo dużym zestarzeniu stali. „Wskaźnik starzenia" $\mathrm{W}_{\mathrm{s}}$, równoważny stosunkowi udarności po zestarzeniu do udarności materiału niestarzonego (próbki N), w poszczególnej temperaturze, od -20 do $+20^{\circ} \mathrm{C}$, wynosi: 0,05; 0,06;0,08; 0,11 i 0,23. Tak niskich wartości współczynnika $W_{s}$ dla badanych próbek $\mathrm{w}$ temperaturze ujemnej nie stwierdzono nawet $w$ mostach eksploatowanych przez okres dwukrotnie dłuższy (przez 140 lat).

Tablica II. Właściwości mechaniczne stali badanej

Table II. Mechanical properties of tested

\begin{tabular}{|c|c|c|c|c|c|c|c|c|c|c|}
\hline \multirow[b]{2}{*}{ Rodzaj stali } & \multirow{2}{*}{$\begin{array}{c}\text { Wymiary } \\
\text { próbki } \\
\text { mm }\end{array}$} & \multirow{2}{*}{$\begin{array}{c}\mathrm{R}_{\mathrm{eH}} \\
\left(\mathrm{R}_{\mathrm{e}}\right) \\
{[\mathrm{MPa}]}\end{array}$} & \multirow{2}{*}{$\underset{[\mathrm{MPa}]}{\mathrm{R}_{\mathrm{eL}}}$} & \multirow{2}{*}{$\underset{[\mathrm{MPa}]}{\mathrm{R}_{\mathrm{m}}}$} & \multirow{2}{*}{$\begin{array}{l}\mathrm{A}_{5} \\
{[\%]}\end{array}$} & \multirow{2}{*}{$\begin{array}{c}\mathrm{Z} \\
{[\%]}\end{array}$} & \multicolumn{4}{|c|}{ Twardość Brinella } \\
\hline & & & & & & & HB5 & $\begin{array}{c}\mathrm{R}_{\mathrm{m}} \\
{[\mathrm{MPa}]}\end{array}$ & $a$ & $\begin{array}{c}\mathrm{R}_{\mathrm{eB}} \\
{[\mathrm{MPa}]}\end{array}$ \\
\hline \multirow{3}{*}{$\begin{array}{l}\text { starzona } \\
\text { (S) }\end{array}$} & \multirow{3}{*}{$\begin{array}{l}\varnothing 10 \\
I=50\end{array}$} & 220 & 209 & 356 & - & - & 106 & 358 & \multirow{3}{*}{0,70} & 250 \\
\hline & & 224 & 210 & 361 & 36 & 69 & 107 & 362 & & 253 \\
\hline & & 227 & 218 & 308 & - & - & 107 & 362 & & 253 \\
\hline \multicolumn{2}{|c|}{ Wartość średnia } & 220 & 212 & 342 & 36 & 69 & 107 & 361 & 0,70 & 252 \\
\hline \multirow{3}{*}{$\begin{array}{l}\text { normaliz. } \\
(\mathrm{N})\end{array}$} & \multirow{3}{*}{$\begin{array}{l}\varnothing 10 \\
I=50\end{array}$} & 275 & 269 & 375 & 40 & 65 & 104 & 350 & \multirow{3}{*}{0,70} & 245 \\
\hline & & 283 & 268 & 376 & 42 & 69 & 105 & 355 & & 248 \\
\hline & & 285 & 271 & 377 & 41 & 66 & 108 & 365 & & 255 \\
\hline \multicolumn{2}{|c|}{ Wartość średnia } & 275 & 269 & 376 & 41 & 67 & 106 & 357 & 0,70 & 249 \\
\hline
\end{tabular}


Jednocześnie należy podkreślić mały rozrzut wartości udarności $w$ danych zakresach temperaturowych, pomimo, że $80 \%$ próbek miało złom z rozwarstwieniami. Uwaga ta dotyczy zarówno próbek N (górne, ciemniejsze na rys. 6) oraz próbek $S$ (dolne, jaśniejsze). Poza tym nieznaczne jest zróżnicowanie wielkości udarności w funkcji temperatury próbek $\mathrm{N}$ w porównaniu z próbkami $\mathrm{S}$. Iloraz wartości udarności w temperaturach skrajnych $\left(+20 \mathrm{i}-20{ }^{\circ} \mathrm{C}\right)$ dla próbek stali normalizowanej $\mathrm{N}$ wynosi jedynie 1,32, a dla stali starzonej $S$ aż 5,69.

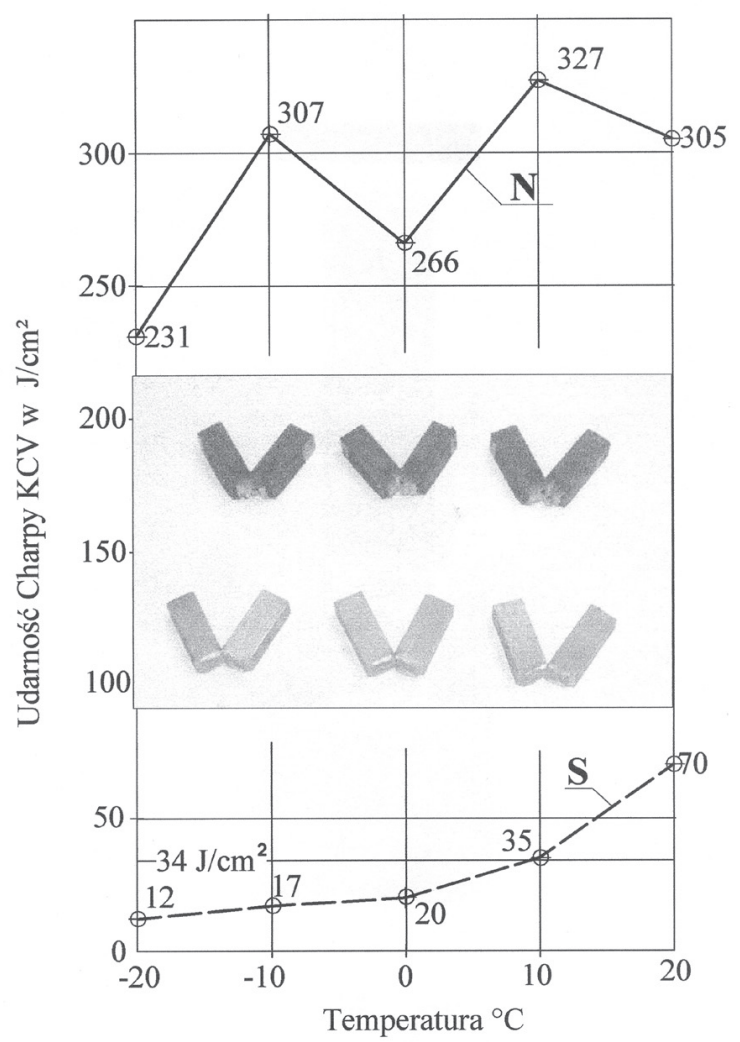

Rys. 6. Średnia udarność próbek ze stali normalizowanej (N) i starzonej (S)

Fig. 6. The average impact strength standard steel $(\mathrm{N})$ and ageing steel (S)

\section{Ocena spawalności stali}

Wykorzystując wyniki badań chemicznych stali mostu oceniono jej spawalność metalurgiczną i konstrukcyjną. W tym celu określono poniższe wskaźniki $[3,6]$.
- równoważnik węgla (dla stali o C < 0,18\%) [12]

$\mathrm{C}_{\mathrm{e}}=\mathrm{C}+\frac{\mathrm{Si}}{30}+\frac{\mathrm{Mn}+\mathrm{Cu}+\mathrm{Cr}}{20}+\frac{\mathrm{Ni}}{60}+\frac{\mathrm{Mo}}{15}+\frac{\mathrm{V}}{10}+5 \mathrm{~B}=0,12 \%<0,41 \%$

- wskaźnik odporności materiału na pękanie gorące

$\mathrm{HCS}=1000\left(\mathrm{~S}+\mathrm{P}+\frac{\mathrm{Si}}{25}+\frac{\mathrm{Ni}}{100}\right) \frac{\mathrm{C}}{3 \mathrm{Mn}+\mathrm{Cr}+\mathrm{Mo}+\mathrm{V}}=1,67 \%<4 \%$

$\mathrm{C}_{\text {ekw }}=\mathrm{C}+2 \mathrm{~S}+\frac{\mathrm{P}}{3}+\frac{\mathrm{Si}-0,4}{10}+\frac{\mathrm{Mn}-0,8}{12}+\frac{\mathrm{Ni}}{12}+\frac{\mathrm{Cu}}{15}+\frac{\mathrm{Cr}-0,8}{15}=0,03 \%<0,15 \%$

- wskaźnik oceny skłonności do pękania zimnego, gdzie $\mathrm{t}=18 \mathrm{~mm}$

$C_{e}^{\prime}=C+\frac{M}{6}+\frac{P}{2}+\frac{M}{4}+\frac{N}{1}+\frac{C}{1}+\frac{C+V}{5}+0,0024 t=0,23 \%<0,41 \%$

- twardość strefy wpływu ciepła

$\mathrm{HV}_{\text {max }}=90+1050 \mathrm{C}+47 \mathrm{Si}+75 \mathrm{Mn}+30 \mathrm{Ni}+31 \mathrm{Cr}=216 \mathrm{HV}<350 \mathrm{HV}$

Stal blachownicowych dźwigarów mostowych jest spawalna bez ograniczeń, gdyż wszystkie obliczone wskaźniki $(1 \div 5)$ dla tej stali są mniejsze od wartości granicznych - rysunek 7 .

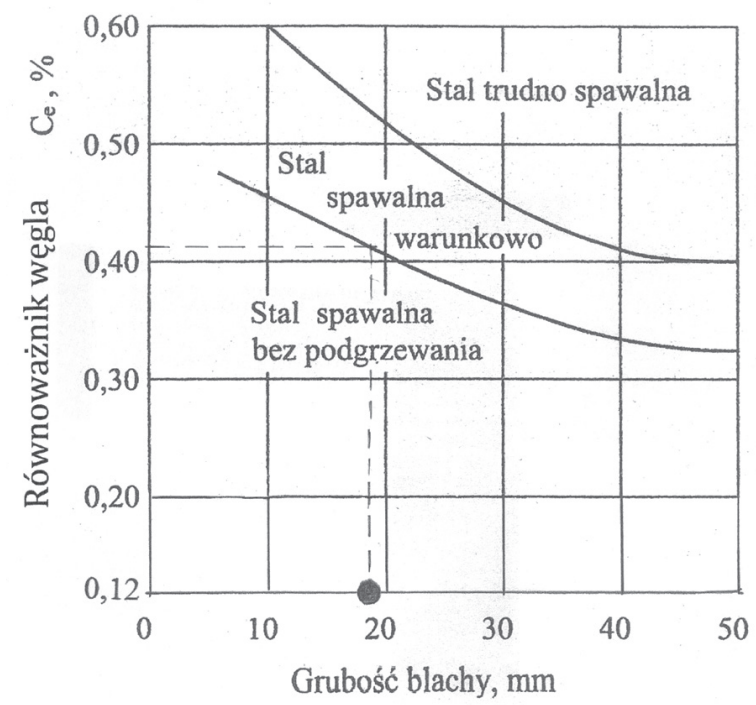

Rys. 7. Zależność spawalności od Ce i grubości blachy

Fig. 7. Function of weldability versus Ce the plate thickness

Tablica III. Udarność próbek Charpy'ego

Table III. Impact strength in Charpy's test

\begin{tabular}{|c|c|c|c|c|c|c|c|c|}
\hline \multirow{2}{*}{ Element } & \multicolumn{2}{|c|}{ Wymiar próbek } & \multirow{2}{*}{$\begin{array}{c}\mathrm{Nr} \\
\text { próbki }\end{array}$} & \multicolumn{5}{|c|}{ Udarność KCV, [J/cm²] } \\
\hline & Przekrój i karb [mm] & Pole $\left[\mathrm{mm}^{2}\right]$ & & $-20^{\circ} \mathrm{C}$ & $-10^{\circ} \mathrm{C}$ & $0^{\circ} \mathrm{C}$ & $10^{\circ} \mathrm{C}$ & $20^{\circ} \mathrm{C}$ \\
\hline $\begin{array}{c}\text { Stal starzona } \\
\text { (S) }\end{array}$ & $\begin{array}{c}10 \times 10 \\
2\end{array}$ & 80 & $\begin{array}{l}1 \\
2 \\
3\end{array}$ & $\begin{array}{l}11,7 \\
12,1 \\
13,2\end{array}$ & $\begin{array}{l}15,4 \\
17,6 \\
17,9\end{array}$ & $\begin{array}{l}19,1 \\
19,3 \\
20,6\end{array}$ & $\begin{array}{l}33,9 \\
34,0 \\
38,6\end{array}$ & $\begin{array}{l}64,4 \\
70,0 \\
75,5\end{array}$ \\
\hline \multicolumn{4}{|c|}{ Wartość średnia } & 12,3 & 17,0 & 19,7 & 35,5 & 70,0 \\
\hline $\begin{array}{l}\text { Stal normal. } \\
(\mathrm{N})\end{array}$ & $\begin{array}{c}10 \times 10 \\
2\end{array}$ & 80 & $\begin{array}{l}1 \\
2 \\
3\end{array}$ & $\begin{array}{l}215,9 \\
234,0 \\
244,0\end{array}$ & $\begin{array}{l}298,6 \\
307,6 \\
315,9\end{array}$ & $\begin{array}{l}262,0 \\
264,0 \\
271,6\end{array}$ & $\begin{array}{l}314,6 \\
329,4 \\
337,8\end{array}$ & $\begin{array}{l}290,9 \\
305,1 \\
320,5\end{array}$ \\
\hline \multicolumn{4}{|c|}{ Wartość średnia } & 231,3 & 307,4 & 265,9 & 327,3 & 305,5 \\
\hline
\end{tabular}




\section{Podsumowanie}

Przeprowadzone badania stali blachownicowych dźwigarów nośnych pozwoliły określić aktualne właściwości stali mostu po 75 latach eksploatacji obiektu. Jest to stal zlewna nieuspokojona ( $\mathrm{Si}=0,045 \%<0,12 \%$ ) o bardzo dużym zestarzeniu. Tak małych wartości „wskaźników starzenia” $W_{s}$ równych od 0,05 do 0,23, nie uzyskali autorzy w dotychczasowych badaniach stali zlewnej mostów użytkowanych przez czas znacznie dłuższy. Temperatura przejścia tej stali w stan kruchy wynosi $+9^{\circ} \mathrm{C}$. Taki stan może być groźny podczas warunków zimowych. Stal mostu jest spawalna bez ograniczeń, gdyż wszystkie obliczone wartości wskaźników: $(1 \div 5)$ są mniejsze od wartości granicznych.

Aktualne wartości wytrzymałościowe tej stali wynoszą: $R_{e}=220 \mathrm{MPa}$ oraz $R_{m}=340 \mathrm{MPa}$ i są one jedynie o $8 \% \mathrm{mniej}-$ sze od wartości zalecanej przez normę DIN 1612 dla stali po wytopie. Wartość $R_{e}=220$ MPa przyjmowano również dla stali St 37S, stosowanej w Polsce w latach 1946-1962, oraz dla stali niemieckiej St 3 i St 3W specjalnie uspokojonych.

Zaskakująco duże wartości udarności Charpy'ego, w zakresie temperatur od -20 do $20{ }^{\circ} \mathrm{C}$, uzyskano z badań próbek stali znormalizowanej (rys. 6). Wyjaśnienie tego zjawiska uzyskano z analizy normy DIN 1612 - 1932 - 01 [9,10]. Norma ta dla konstrukcji budowlanych określa dane czterech stali gatunków: St37 12, St34 12, St42 12 , St44 12. Trzy ostatnie stale to stale zwykłej jakości (Sondergüte), a jedynie stal St37 12 jest stalą normalizowaną (Normalgüte), której początek produkcji literatura niemiecka szacuje już na rok 1896 [11]. Obróbka cieplna w postaci wyżarzania normalizującego jest stosowana w celu rozdrobnienia ziaren. Według [12], jedynym czynnikiem zwiększającym granice plastyczności i jednocześnie obniżającym temperaturę przejścia stali w stan kruchy jest rozdrobnienie ziarna. Fakt ten świadczy, że stal przedmiotowego mostu to stal gatunku St 37 12. Wyniki badań tej stali po starzeniu nie są odnotowane w żadnej znanej autorom artykułu literaturze technicznej. Z tego powodu przedstawione badania należy traktować jako unikatowe. Czynniki metalurgiczne wpływające na obniżenie udarności stali omówiono w [12]. Badania te mają znaczenie praktyczne, gdyż wg Eurokodu 3 obecnie konstrukcje mostowe należy wykonywać ze stali S355 o klasach jakości K2, N, M, NL i ML po walcowaniu normalizującym (N, NL) bądź po walcowaniu termomechanicznym. Rodzi się pytanie: czy stale te będą wykazywały również tak duże starzenie w okresie swojej eksploatacji, jak badana stal St 37 12? W celu oszacowania tych czynników i częściowego wyjaśnienia procesów degradacji mikrostruktury stali mostu, podjęto próbę badań metalograficznych, których wyniki zostaną przedstawione w oddzielnym artykule.

\section{Literatura}

[1] Wysokowski A.: Trwałość mostów stalowych w funkcji zjawisk zmęczeniowych i korozyjnych. Studia i materiały, zeszyt 53, IBDiM, Warszawa 2001.

[2] Ambroziak A., Pękalski G., Rabiega J.: Propozycje metod oceny stanu degradacji stalowych konstrukcji mostowych z przełomu XIX i XX wieku. Wrocławskie Dni Mostowe - Mosty stalowe. Projektowanie, technologie budowy, badania, utrzymanie. Wrocław 2008.

[3] Hołowaty J., Wichtowski B.: Testing the Properties of Structural Cast Steel (Flußstahl) in Old Railway Bridges. IABSE Conference, Rotterdam 2013.

[4] Wiśniewski D., Majka M., Bień J.: Ocena nośności mostów w okresie ich eksploatacji - doświadczenia krajowe i zagraniczne. „Inżynieria i Budownictwo", nr 7-8/2013.

[5] Dudziński W., Pękalski.: Materiałowe aspekty teorii degradacji. Materiały XIII konferencji sprawozdawczej „Metalurgia 2002”, tom 2. Komitet Metalurgii PAN, Krynica 2002.
[6] Wichtowski B., Woźniak Z.: Właściwości stali zlewnej kratownicowego mostu kolejowego po 122 latach eksploatacji. „Inżynieria i Budownictwo", nr 4/2006.

[7] Wichtowski B., Hołowaty J.: Analiza właściwości materiałowych i spawalności stali zlewnej mostów kolejowych. „Inżynieria i Budownictwo", nr 5/2013.

[8] Hołowaty J., Wichtowski B.: O stanie technicznym najstarszego w Polsce wiaduktu drogowego ze stali zlewnej. „Inżynieria i Budownictwo", nr $7-8 / 2013$.

[9] DIN 1612: 1932 - 01 Flußstahl gewalzt - Formstahl, Stabstahl, Breitflachstahl (Alte Bezeichnung, Formeisen, Stabeisen, Universaleisen).

[10] Stahl im Hochbau. Taschenbuch fur Entwurf, Berechnung und Ausfuhrung von Stahlbauten. Verlag Stahleisen m. b. H. Düsseldorf 1935.

[11] Schaper G.: Stählerne Brücken. Verlag von Wilhelm Ernst and Sohn, Berlin 1949.

[12] Blicharski M.: Inżynieria materiałowa. Stal. WN-T, Warszawa 2004. 